\title{
PENGEMBANGAN MENTAL MAP DALAM PEMBELAJARAN GEOGRAFI DI SEKOLAH
}

\author{
Rayuna Handawati \\ Dosen Prodi Pendidikan Geografi, Fakultas Ilmu Sosial Universitas Negeri Jakarta \\ Kampus A Gedung K. FIS UNJ lantai 2 JI. Rawamangun Muka Jakarta 13220 Indonesia \\ rhandawati@unj.ac.id
}

\begin{abstract}
Abstrak
Mental map sebagai gambaran tentang suatu wilayah dan lingkungannya, yang dikembangkan oleh individu atas dasar pengalaman sehari-hari dari berbagai sumber, antara lain dapat diperoleh melalui pembelajaran di sekolah dari guru dan media. Alat ukur keakuratan mental map seseorang terhadap suatu wilayah adalah mengkonfirmasi atau menerjemahkan dalam peta kartografis. Namun bersama peta kartografis, spektrum mental map peserta didik dapat dikembangkan tidak hanya berupa pengetahuan dan persepsi tentang lokasi geografis dari suatu obyek di permukaan bumi, peserta didik juga dapat melihat hubungan antar fenomena di permukaan bumi, pola, persamaan dan perbedaan hingga interdependensi suatu tempat dengan menerapkan prinsip dan pendekatan geografi. Mental map yang baik dan berkembang akan berguna bagi peserta didik dalam membuat keputusan untuk kepentingan pribadi hingga memberikan solusi kepada masyarakat. Guru berperan mendesain pembelajaran yang dimulai dari perencanaan, pelaksanaan dan evaluasi yang mengembangkan mental map. Setiap pokok bahasan geografi pada mata pelajaran geografi dijelaskan dengan sudut pandang geografi dalam skala lokal, regional dan global. Setiap pokok bahasan geografi di sekolah juga harus menerapkan prinsip maupun pendekatan geografi untuk memaksimalkan mental map peserta didik terhadap lingkungan tempat tinggalnya, negaranya dan internasional sesuai tujuan pembelajaran geografi di sekolah.
\end{abstract}

keyword: mental map, pembelajaran, pembelajaran geografi

\section{Definisi dan Ruang Lingkup Mental Map}

Terminologi mental map secara tidak langsung diperkenalkan pertama kali oleh Kevin Lynch dalam bukunya The Image of City pada tahun 1960, kemudian digunakan secara lugas oleh Peter Gould dan Rodney White dalam bukunya Mental Maps pada tahun 1974 untuk menggambarkan persepsi yang dimiliki seseorang terhadap tempat.

Mental map atau peta mental (Mutakin, 2008, hlm. 209) memiliki pengertian yang sama dengan peta kognitif(cognitive map), signature kognitif dan schemata sebagaimana dinyatakan oleh Abdurachman (1988, hlm. 27). Istilah cognitive map dikemukakan oleh seorang ahli geografi bernama Roger Downs bersama ahli psikologi bernama David Stea pada tahun 1973. Keduanya memberikan definisi cognitive map sebagai "the product of a series of psychological processes that register, codes, stores, recalls, and decodes information about the relative locations and attributes of phenomena in his everyday spatial environment (Nelson, 1996, hlm. 229). Sementara Schenk (2013, hlm. 2) memberikan perbedaan bahwa cognitive map lebih banyak digunakan dalam bidang ilmu psikologi lingkungan, sementara mental map lebih sering digunakan dalam bidang ilmu geografi.

Beberapa pengertian dari mental map antara lain menurut Miller (1972, hlm. 61) dalam Abdurachman (1988, hlm. 29), mental map adalah semua pengetahuan yang terkumpulkan dan terorganisasikan yang dimiliki oleh organisma tentang dirinya sendiri dan tentang dunianya, meliputi segala sesuatu yang telah dipelajari oleh organisma tersebut, 
nilai-nilai budaya, fakta-fakta bagi dirinya, yang terorganisasikan konsep-konsep, khayalan, atau hubungan-hubungan yang telah dikuasai oleh orang-orang yang bersangkutan. Sementara berdasarkan Academic Standard for Geography dari Pennsylvania Department of Education (2002, hlm. 17) memberikan definisi mental map sebagai "a geographic representation which conveys the cognitive image a person has of an area, including knowledge of features and spatial relationships as well as the individual's perceptions and attitudes regarding the place; also known as a cognitive map". Stea (1973) secara ringkas juga memberikan definisi mental map sebagai gambaran di luar kepala terhadap suatu tempat atau wilayah. Definisi ini sejalan dengan pernyataan Milgram (1972) and Lynch (1960) dalam (Sudas dan Gokten, 2012, hlm. 42) dengan menggunakan istilah cognitive maps memberikan definisi mental map sebagai "the inner images that are developed by the individual about a place. Cognitive maps are the main tools that are used to identify spatial images and the difference between physical and subjective environment".

Lebih jauh, Downs and Stea (1973) menegaskan bahwa cognitive maps as "an abstraction covering those cognitive or mental abilities that enable us to collect, organize, store, recall and manipulate information about the spatial environment". Oleh karena itu pendapat yang menyebutkan mental map sama dengan mind map akan menemukan kesalahan yang fatal. Buzan and Buzan (1993) dalam Sudas dan Gokten (2012, hlm. 42) juga memberikan tambahan penjelasan bahwa konsep mental map berbeda dengan mind map, dimana ia memberikan pengertian bahwa "mind mapping is also used in a different sense which is more depends on organizing information through categories and hierarchies".

Abdurachman (1988, hlm. 27) selanjutnya menjelaskan bahwa penggunaan istilah peta dalam mental map atau cognitive map hanya merupakan suatu analogi fungsional. Perhatian utama ialah pada representatif kognitif yang merupakan fungsi yang umum dalam peta kartografis, tetapi tidak perlu mempunyai sifat-sifat fisik dari model grafik gambar tersebut. Peta kartografis dan peta kognitif mempunyai fungsi yang sama, tetapi tidak mempunyai struktur yang sama, analoginya bukan analogi proses, melainkan analogi hasil. Pengertian yang sama berdasarkan Downs dan Stea (1973) dalam Barkowsky (2002, hlm. 23) "The cognitive map is similar to external spatial knowledge representations like geographic maps in some respects. Spatial tasks are performed on the internal map in a similar way as on an external map in the given situation".

Oleh karena itu, Getis dan Fellmann (2006, hlm. 272 - 273) mengemukakan mendiskusikan mental map berarti membicarakan definisi peta itu sendiri. Peta dikatakan sebagai sesuatu yang membentuk pemahaman tentang distribusi dan lokasi atau mempengaruhi persepsi seseorang tentang dunia di sekitarnya dan tidak selalu digambar di atas kertas. Keduanya memberi pengertian mental map sebagai gambaran tentang suatu daerah atau lingkungan yang dikembangkan oleh individu atas dasar informasi atau tayangan yang diterima, ditafsirkan, dan disimpan. Kapanpun seseorang berpikir tentang tempat dan bagaimana mencapai tempat, maka sudah dapat dikatakan menghasilkan mental map. Kesadaran seseorang terhadap tempat-tempat biasanya diketahui diringi dengan pendapat tentang tempat tersebut, tetapi tidak ada hubungan antara kedalaman pengetahuan dan persepsi yang terbentuk. Secara umum, semakin familiar terhadap lokasi, semakin baik fakta dasar gambaran mental map seseorang terhadap lokasi tersebut. Dengan kata lain setiap kali orang berpikir tentang tempat atau bagaimana untuk sampai ke tempat, disini dikatakan seseorang menghasilkan mental map.

Mental map setiap orang akan berbeda-beda dan sangat subyektif karena berbagai faktor yang mempengaruhinya. Dapat dikatakan setiap individu memiliki mental map terhadap dunia, tetapi tidak ada satu orangpun memiliki gambaran terhadap dunia lengkap dan benar. Gambaran yang rinci terhadap suatu bagian tempat dari bumi tidak lepas dari keakraban seseorang pada tempat tersebut. Oleh karena itu, secara sederhana dapat dikatakan mental 
map terbaik yang dimiliki oleh kebanyakan orang adalah mental map lingkungan perumahannya sendiri, tempat dimana menghabiskan waktu paling banyak. Semakin baik dasar faktual yang dimiliki seseorang terhadap suatu tempat, semakin baik mental map-nya.

Dari berbagai literatur hasil penelitian, salah satu cara atau metode untuk memastikan bagaimana mental map individu seseorang adalah dengan bertanya apa yang mereka pikirkan tentang suatu tempat atau dituangkan dalam bentuk peta sketsa seperti yang dilakukan oleh Benson (2002) dan Nelson (1996). Orang-orang dengan pengalaman serupa cenderung memberikan jawaban serupa dengan pertanyaan tentang lingkungan dan menghasilkan peta sketsa yang kira-kira akan sama sebagaimana pendapat Fellman (1999) bahwa orang akan memiliki jawaban atau keputusan yang sama dengan yang lain jika memiliki pengalaman yang sama tentang suatu wilayah terutama dari informasi yang bersifat umum. Cara lain yang lebih kompleks seperti yang dilakukan Heatwole (1993) adalah dengan mengurutkan tempat-tempat terbaik hingga tempat terburuk di negaranya dan selanjutnya menjadi keputusan pilihan dimana akan tinggal, atau sekedar menyusun tempat terbaik hingga terburuk dengan dasar-dasar pertimbangan lainnya.

Namun demikian karakteristik dari mental map yang bersifat subyektif dapat diukur secara tepat dengan keadaan sebenarnya dengan mengkonfirmasinya pada kondisi lingkungan yang sebenarnya. Oleh karena itu dalam Geography For Life (1994; hlm. 64) karakteristik dari mental map dideskripsikan antara lain sebagai

"are personal and idiosyncratic and are usually a mixture of both objective knowledge and subjective perceptions. They contain objective and precise knowledge about the location of geographic features such as continent, counteries, cities, mountain ranges, and oceans. They also contain more subjective and less precise information, such as impressions of places, rough estimates of relative size, shape, and location, and a general sense of certain connections between places, as well aspriorities that reflect the mapmaker's own predilections".

Perkembangan ilmu pengetahuan dan teknologi dapat membantu mengkonfirmasi gambaran seseorang terhadap lingkungan dan dunia tempat tinggalnya. Seperti adanya satelit yang menghasilkan citra dengan resolusi tinggi dan kegiatan ground check oleh ahli bidang geografi untuk menghasilkan peta kartografis.

Peta kartografis merupakan alat yang berguna untuk mengembangkan mental map dengan asumsi bahwa seseorang dapat mengenal lingkungan dengan lebih baik jika menggunakan peta kartografis. Seseorang dapat bergerak dengan bebas secara fisik dan mental bahkan mengadakan analisa hubungan jika menggunakan peta kartografis. Namun demikian di awal adanya peta kartografis, manusia menciptakannya melalui penjelasan suatu letak lokasi/objek geografi berdasarkan peta yang ada di benak manusia. Hal ini dipertajam dari penelitian oleh Gould (1986, hlm. 30) "The perception that people have of places, and the mental images that are formed from filtered information flows..." Hasil saringan dari berbagai komponen informasi dari berbagai individu dilist dan diolah untuk selanjutnya dipetakan secara kartografis seperti yang ditunjukkan pada Gambar 2.1 di bawah ini. 


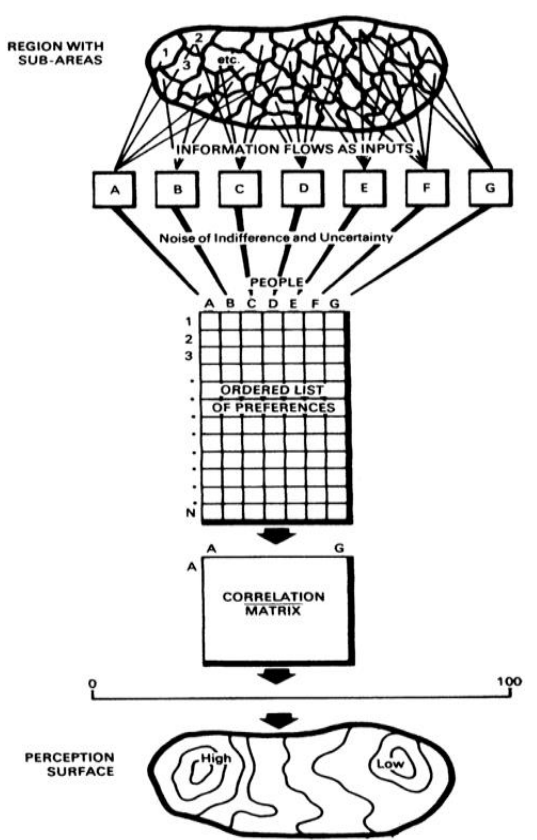

Sumber: Mental Map (Gould, 1986, hlm. 31)

Gambar 2.1. Konstruksi pemilihan muka bumi dari informasi mentah terhadap mental map muka bumi akhir.

Secara sederhana mental map seseorang yang tertuang dalam peta kartografis maupun tidak, dapat diukur melalui aspek-aspek sebagai berikut antara lain:

1. Tanda-tanda yang mencolok (landmarks),

2. Jalur-jalur jalan (paths) yang menghubungkan satu tempat dengan tempat yang lain,

3. Titik temu antar jalur (nodes) misalnya pertigaan atau perempatan,

4. Batas-batas wilayah (edges) yang membedakan satu wilayah dan wilayah lainnya. Misalnya, kompleks perumahan dibatasi oleh sungai.

5. Distrik, yaitu wilayah-wilayah homogen yang berbeda dari wilayah-wilayah lain. Misalnya, pusat perdagangan ditandai oleh bangunan bertingkat dengan lalu lintas yang padat (Lynch, 1960 dalam Purwanto, 2001, hlm. 90)

Oleh karenanya secara ideal, menurut Abdurrahman (1988, hlm. 42) mental map (peta mental) dan peta kartografis harus menjadi satu dalam pembelajaran geografi di sekolah atau untuk keperluan lainnya. Sejalan dalam Geography For Life (1994) mental map sangat berguna untuk setiap orang selama hidupnya. Mental map yang semakin baik memungkinkan orang untuk mengetahui rute terbaik yang akan diambil ketika berpergian sejak keluar rumah misal untuk menempuh waktu tercepat, menghindari macet ataupun lokasi berbahaya. Lebih jauh mental map dapat membangun konsep interdependensi dan interrelasi sehingga memahami dunia lebih baik.

"Mental maps represent ever changing summaries of spatial knowledge and serve spatial characteristics of places. People develop and refine their mental maps both through personal experience and through learning from teachers and the media. They refine at least some of their maps to ever higher level of completeness and accuracy, and they continue to add information so that the maps reflect a growing understanding of a changing world. Critical geographic observation is essential to this development and refinement proces, because mental maps reflect people's skill in observing and thingking about the world in spatial terms (and have nothing to do with their ability to draw)".

Penjelasan berikutnya dalam Geografi For Life (1994; hlm. 64 - 66) adalah bagaimana mental map terbentuk pada peserta didik dari pembelajaran geografi

"As student read, hear, observe, and think more about the world around them, they can add more detail and structure to their mental maps acumulate multiple layers of useful information, and the growth in complexity and utiliy can provide them with a sense of satisfaction as more places and events in the world can be placed into meaningful spatial context...If geography is to be useful in creating a framework for understanding the world past, present, and future-then coherent mental maps must take take shape and become increasingly refined as students progress through their school years. Student should be encouraged to develop and update their mental maps to ensure that they continue to have essential knowledge of place 
location, place characteristics, and other information that will assist them in personal desicion-making and in establishing a broad-based perception of Earth from a local to global prepective. In addition, they need to understand that developing mental maps is a basic skill for everyone who wants to engage in a lifetime of geographic understanding".

Dari berbagai pengertian di atas, mental map adalah pengetahuan yang dimiliki tiap individu tentang suatu tempat atau lokasi yang diperoleh dari berbagai sumber seperti pengalaman sehari-hari, melakukan perjalanan maupun diperoleh dari pembelajaran di sekolah dari guru dan media yang dapat diungkap sewaktu-waktu untuk menjawab pertanyaan-pertanyaan bersifat geografi atau dituangkan dalam peta sehingga diharapkan mampu terlibat dalam memecahkan masalah sosial. Mental map menjadi produk dari hasil pembelajaran geografi yang diperoleh secara bertahap melalui pengalaman belajar.

Dalam konteks pembelajaran, terdapat berbagai standar untuk mengukur mental map peserta didik. Social Studies Standards-Geography (2011) yang dikembangkan oleh Delaware Department of Education memberikan kategori mental map dalam konteks pendidikan geografi sebagai berikut

A mental map is a person's internalized picture of a part of the Earth's surface. It helps make sense of the world by storing and recalling information about the patterns of the Earth's human and natural features. A welldeveloped mental map is a great asset in understanding local, national, and world events. Students need to develop mental maps that reflect the relative location and knowledge of major landforms and climatic zones, human settlements, political divisions, and economic activities at local, state, national, and world scales. Students also need to develop the ability to create, use, and interpret maps and other geographics crucial to analyzing and solving geographic problems.

Sementara Bednardz, S, W, dkk dalam Geography For Life (1994, hlm. 64) mengemukakan batasan lingkup dalam mengembangkan mental map adalah

Such a map is an individual's internalized representation of some aspect or aspects of Earth's surface. It represents what the person knows about the locations and characteristics of places at a variety of scale (local to global), from the layout students's bedroom to the distribution of oceans and continents on the surface of Earth. These maps in the mind provide students with an essential means of making sense of the worlds, and of storing and recalling informatian about the shapes and patterns of the physical and human features of Earth. Learning how to create and use mental maps, therefore, is a fundamental part of the process of becoming geographically informed.

Geography Education National Implementation Project menyusun standar untuk pembentukan dan pengembangan mental map bagi peserta didik dalam berbagai jenjang pendidikan. Standar mental map untuk tingkat SMA atau yang disebut tingkat 9 hingga tingkat 12 diukur melalui berbagai indikator sebagai berikut (National Geographic Society, 2012):

1. Identify from memory and explain the locations, characteristics, patterns, and relationships among human and physical systems.

2. Explain the development of completeness and accuracy in the student's mental map of places and regions.

3. Identify from memory and explain the locations, characteristics, patterns, and relationships of places and regions to answer geographic questions.

Sementara indikator dari mengukur mental map yang dikembangkan oleh Canadian National Standards For Geography adalah

Use maps drawn from memory to answer geographic questions by sample learning activity e.g:

1. Prepare a sketch map to illustrate the spatial dynamics of contemporary and historical events (e.g., the spread of the bubonic plague in fourteenth-century Europe or the historical development of population centres and settlement patterns in Canada).

2. Illustrate the spatial dynamics of contemporary and historical events.(e.g., the importance of the Great Lakes-St. Lawrence system on development of the urban and industrial heartland of central Canada). 
3. Have students develop mental maps of where they would expect major fishing or farming regions to be in Canada or mining areas to get a mental map image of the Canadian Shield.

Academic standard for geography yang dikembangkan Pennsylvania Department of Education (2002: hlm.5) menetapkan mental map pada siswa kelas 9 - 12 digunakan untuk "...organize and understand the human and physical features of the United States and the world...". Sementara Delaware Department of Education dalam Social Studies Standards-Geography (2012, hlm. 10) menetapkan standar mental map untuk siswa pada level 9 - 12 atau sekolah menengah atas sebagai berikut:

- Mental maps summarize differences and similarities about places. These differences and similarities lead to conflict or cooperation and the exchange of goods and ideas between peoples.

- Mental maps change as the scale moves from local to global; we know more about our home area than more distant places; and these differences affect how we feel and behave towards places that are distant versus those that are close.

- The ways mapped patterns are analyzed and used help solve societal problems

- Maps can be used to distort or introduce bias into the information they portray.

Level 9-12a : Students will identify geographic patterns which emerge when collected data is mapped, and analyze mapped patterns through the application of such common geographic principles as

-- Hierarchy (patterns at a detailed scale may be related to patterns at a more general scale)

-- Accessibility (how easily one place can be reached from another)

-- Diffusion (how people or things move in certain directions at certain speeds)

-- Complimentarity (the mutual exchange of people or goods among places usually occurs over the shortest possible distances)

Level 9-12b : Students will apply the analysis of mapped patterns to the solution of problems.

Secara ringkas dari paparan standar mental map yang ditetapkan oleh beberapa institusi pendidikan bidang geografi bahwa seorang siswa kelas 9 - 12 atau SMA harus memiliki kemampuan untuk menjawab pertanyaan geografi yang terkait dengan antara lain 1) mampu menggambarkan fenomena fisik dan sosial; 2) mampu menjelaskan lokasi, karakteristik, pola dan hubungan antar tempat dan wilayah; 3) menjelaskan persamaan dan perbedaan fenomenan fisik dan sosial di muka bumi 4)mengetahui lebih tentang wilayah tempat tinggalnya dari daerah lainnya; 4) melalui pola fenomena fisik dan sosial dapat menemukan solusi untuk masalah; 5) mampu menggambarkan dan menganalisis pola geografis yang terpetakan melalui penerapan prinsip umum geografi seperti hirarki, aksesibilitas, persebaran, saling berhubungan (interaksi) dan saling melengkapi (interdependensi).

Melalui ikhtisar dari pengertian mental map dapat diketahui bahwa mental map adalah kemampuan yang harus dimiliki setiap orang mengenali lingkungan tempat hidupnya sehingga dapat dimanfaatkan dalam menjalani kehidupannya di muka bumi. Secara khusus mental map dalam pembelajaran geografi adalah kemampuan geografis yang diperoleh peserta didik selama dan sesudah mempelajari geografi untuk melangsungkan kehidupannya. Artinya penerapan mental map dalam pembelajaran geografi adalah mempelajari geografi itu sendiri. Sebagaimana beberapa pengertian dari pembelajaran geografi itu sendiri.

\section{Pembelajaran Geografi}

Hartshorne (1960, hlm. 47) pada bukunya Prespective on The Nature of Geography menyatakan bahwa geografi adalah "...seeks to describe and interpret the variable character from place to place of the earth as the world of man". Pendapat ini dilanjutkan dengan penjelasan Hartshorne bahwa

"...geographers should concentrate on explaining the interrelations of the features of the earth using either "social laws" or "natural laws" as the situation demands. The influence of people on the landscape and the impacts of the natural environment on human activities were of equal significance and were equally useful in explaining the nature of a place, region, or geographic feature (dalam Otten, 2014) 
Pendapat lain dari Bergman dan Renwick (2003; hlm. 4) yang didasarkan pada pendapat umum "knowing place names is a tool for studying geography" mendefinisikan geografi sebagai "the study of the interaction of all physical and human phenomena at individual places and of how interactions among places from patterns and organize space". Selanjutnya geografi yang diterjemahkan pada aktivitas pendidikan formal memiliki beberapa pengertian yang lebih spesifik. Council of the Geographical Association 1919 (dalam Sumaatmadja, 1997, hlm. 10 - 11) merumuskan "Geography then deals with the real world, ... This envolves relations with the natural sciences. It deals with the way in which this material world has influenced man, and in turn has been modified, an altered and adapted by human action".

Secara spesifik definisi pembelajaran geografi yang dikembangkan oleh Australian Teacher Association menyatakan adalah

Geography is the study of the interaction between people and environment. It develops knowledge and understanding of the distribution of human and natural phenomena. Spatial perspectives underpinning the discipline provide a means for describing and interpreting pattern and processes affecting Earth and its people, and providing students with an understanding, identification and sense of place. For geographer, place is an identifiable part of the Earth's surface with spatial boundaries.

Sementara Canadian Council For Geographic Education (CCGE) mendefinisikan pembelajaran geografi sebagai "is the study of places on the Earth and their relationship with each other... Thus, geography provides a conceptual link for children between home, school and the world beyond. Geographers study how people interact with the environment and region in order to draw generalization about the complex world in which we live. Pengertian ini sejalan dengan pendapat Dublin (1999, hlm. 6) dalam konteks materi pembelajaran yaitu "the study of the Earth, its inhabitants and the interrelationship between them in the context of place, space and environment. It is concerned with the nature, distribution and interaction of human and natural features over the Earth's surface, the processes which create, sustain or change these features, and the contribution they make to the distinctive character of places".

Pakar Geografi Indonesia pada Seminar dan Lokakarya Peningkatan Kualitas Pengajaran Geografi di Semarang tahun 1988 merumuskan "geografi adalah ilmu yang mempelajari persamaan dan perbedaan fenomena geosfer dengan sudut pandang kelingkungan atau kewilayahan dalam konteks keruangan". Dimana pengertian ini sekaligus menegaskan bahwa objek yang menjadi studi geografi adalah geosfer, yaitu permukaan bumi yang pada hakikatnya merupakan bagian dari bumi yang terdiri dari atmosfer, litosfer, hidrosfer dan biosfer yang ditinjau dari sudut pandang kewilayahan dan kelingkungan yang menampakkan persamaan dan perbedaan. Sementara Alfandi (2001, hlm. 87) yang menegaskan objek studi geografi, yaitu:

Objek studi geografi adalah gejala alam (struktur pola, fungsi, proses) dan perilaku serta aktivitas budi daya manusia di permukaan bumi (di geosfer), yang dikaji lokasinya, integrasinya, persebarannya, perkembangannya, interaksinya, dalam lingkup keruangan, kewilayahan, ekologis, system, dan sejarah perkembangannya, dalam lingkup wilayah kajian sebagai suatu keseluruhan (holistic) dan bagian dari keseluruhan wilayah kajian secara lebih mendalam, sehingga dapat diperoleh gambaran tentang perbedaan dan persamaan antar daerah satu dengan daerah lainnya.

Selanjutnya Sumaatmadja (1996, hlm.35) dalam konteks pelaksanaan pembelajaran geografi yang berlangsung di kelas lebih spesifik memberikan pengertian pembelajaran geografi sebagai berikut

Pembelajaran geografi adalah proses dan interaksi antara guru dan murid dalam menelaah interaksi, interelasi dan integrasi gejala-gejala di permukaan bumi yang diungkapkan dengan pertanyaan apa, dimana, mengapa, dan bagaimana? Dimana geografi diajarkan di tingkat sekolah dasar dan sekolah menengah sehingga penjabaran konsep-konsep, pokok bahasan, dan sub pokok bahasannya harus disesuaikan dan diserasikan dengan pengalaman dan perkembangan mental anak pada jenjang-jenjang pendidikan yang bersangkutan. 
Sementara menurut Favier (2011, hlm. 666) dalam Setiawan (2013) menyatakan bahwa

Pembelajaran geografi tidak hanya sekedar mengetahui lokasi dari suatu negara atau karakteristik tempat atau region. Pembelajaran geografi modern tidak sekedar menyampaikan pengetahuan dari guru kepada siswa, tetapi ada aktivitas dari siswa untuk membangun pengetahuannya. Siswa seharusnya membangun pengetahuan, keterampilan, dan motivasi untuk terlibat dalam penyelidikan geografi (geographic inquiry).

Dalam praktik pembelajaran geografi di Indonesia, menurut Purwanto (2010) pembelajaran geografi di sekolah masih mengutamakan atau menonjolkan ilmu bantunya hingga peserta didik berpikir ilmu bantu itu adalah geografi. Peserta didik tidak diajarkan geografi sesuai dengan pengertian dan ruang lingkup geografi serta menggunakan pendekatan geografi, apa yang tertulis di buku teks itu yang guru ajarkan pada peserta didik. Kondisi ini seharusnya sudah ditinggalkan oleh guru geografi manakala gencarnya tuntutan penerapan pendekatan saintifik pada kurikulum 2013. Silabus Geografi SMA edisi revisi tahun 2016 semakin memperjelas bagaimana seharusnya pelaksanaan pembelajaran geografi di SMA. Mata pelajaran geografi harus dirumuskan dari sudut pandang prespektif geografi. Cara pandang geografi terhadap dinamika lingkungan fisik dan lingkungan masyarakat akan dilihat dari aspek integrasi keruangan dan interdependensi ruang baik antar tempat maupun antar skala. Harapan dari Silabus Geografi 2013 tersebut adalah perspektif geografi dapat diwujudkan dalam bentuk nyata maupun abstrak (dan atau representasi) baik secara visual, verbal, matematis, digital, maupun dalam pola pikir (kognitif).

Merujuk dari definisi pembelajaran secara umum yang dikemukakan oleh Gagne dan Briggs (1992, hlm. 3) yaitu pembelajaran adalah suatu sistem yang bertujuan untuk membantu proses belajar peserta didik, yang berisi serangkaian peristiwa yang dirancang, disusun sedemikian rupa untuk mempengaruhi dan mendukung terjadinya proses belajar peserta didik yang bersifat internal, maupun pendapat Gagne (1992, hlm. 3) "...instruction is a set of event that effect learners in such a way that learning is facilitated...", serta pendapat Ningrum dan Waluya (2008) dan Sukmadinata (2004) bahwa pembelajaran (learning) diarahkan pada kegiatan yang sengaja diciptakan guru agar peserta didik belajar. Kegiatan yang disengaja, artinya pembelajaran ini sudah benar-benar disiapkan mulai dari perencanaan sampai pelaksanaannya dalam bentuk suatu desain pembelajaran, pelaksanaan dan evaluasi dan refleksi bagi penyusunan rencana pembelajaran berikutnya. Pengembangan mental map harus direncanakan, diterapkan dan dievaluasi dalam pembelajaran.

\section{Pengembangan Mental Map Dalam Pembelajaran Geografi}

Peserta didik yang mendapatkan pengalaman belajar yang sesuai dengan definisi pembelajaran geografi itu sendiri maka secara otomatis akan dapat mengembangkan mental map-nya sesuai dengan lingkup materi yang diajarkan sekolah. Dengan kata lain, pembelajaran geografi adalah pembelajaran yang mengembangkan mental map peserta didik, baik dalam perencanaan, pelaksanaan dan evaluasi. Praktik pembelajaran geografi yang mengabaikan pengertian dari pembelajaran geografi itu sendiri akan menurunkan daya serap dan kapasitas mental map peserta didik sesuai tuntutan tiap jenjang pendidikan, termasuk mengurangi jangkauan wilayah dan informasi yang dapat diperoleh peserta didik. Peserta didik tidak akan mudah sekedar menyebutkan nama dan menunjuk lokasinya di peta dari satu provinsi di Indonesia sebagai jenjang terendah dari mental map jika tidak pernah mendapatkan pengalaman belajar yang mengarahkannya belajar sedemikian rupa. Demikian pula jika peserta didik tidak pernah mendapatkan pengalaman belajar memetakan wilayah administrasi dan potensi fisik dan sosial tempat tinggalnya. 
Oleh karena itu, sebagaimana indikator yang disusun oleh berbagai institusi bidang Pendidikan geografi di dunia untuk mengembangkan mental map peserta didik di Indonesia, dimana mental map tidak disebutkan langsung sebagai tujuan pembelajaran (nurturant effect), perlu upaya mengintegrasikan nilai-nilai mental map pada pembelajaran. Pada tahap perencanaan seperti penyusunan Rencana Pelaksanaan Pembelajaran (RPP), selain menerjemahkan Kompetensi Dasar (KD) yang termaktub dalam silabus, guru harus menyisipkan atau menuliskan adanya upaya menerapkan:

\section{Prinsip $5 \mathrm{~W}+1 \mathrm{H}$}

Prinsip $5 \mathrm{~W}$ yaitu who/what, where, when, why dan how diterapkan ketika menjelaskan materi pembelajaran. Guru diharapkan menjelaskan tiap pokok bahasan berawal dari "who atau what" hingga melihat pada proses "how". Seperti dicontohkan dalam Geographic Perspective: Content Guide For Educators (2006) peran pertanyaan "why"dan "how" memberikan pengaruh yang sangat signifikan untuk menjelaskan fenomena fisik dan sosial yang ada di permukaan bumi, termasuk terdapat keunikan pada suatu wilayah, persamaan dan perbedaan antar wilayah.

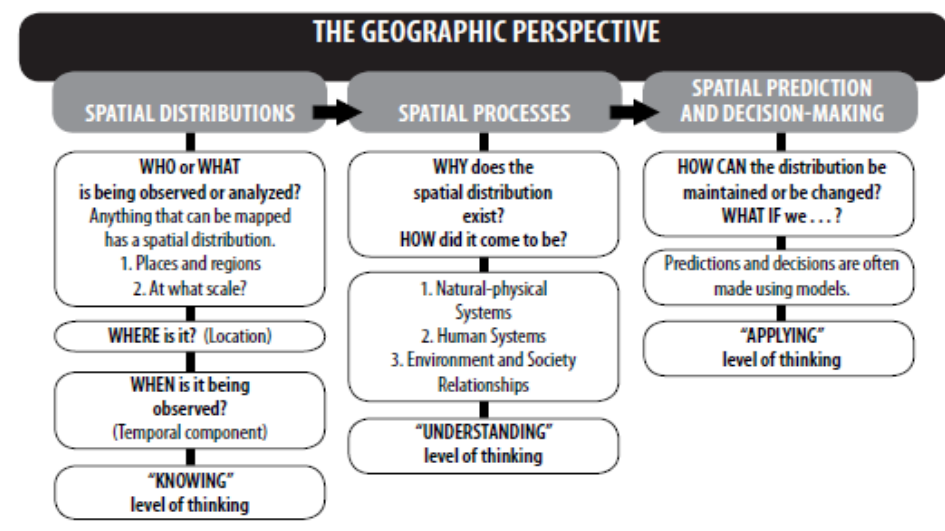

Sumber: National Geographic Society (2006)

2. Prinsip dan pendekatan geografi.

Mengacu pada standar mental map peserta didik dalam pembelajaran geografi, antara lain peserta didik dapat mengidentifikasi dan menerjemahkan pola, perbedaan dan persamaan, membangun interdependensi, interrelasi, aksesibilitas, dan sebagainya, maka penerapan prinsip-prinsip dan pendekatan geografi menjadi keharusan dalam pembelajaran geografi pada setiap pokok bahasan.

Penerapan prinsip dan pendekatan geografi terintegrasi pada materi pembelajaran, media pembelajaran, strategi maupun penggunaan model pembelajaran. Dalam hal ini guru harus berusaha memahami karakteristik materi/pokok bahasan. Pokok bahasan dapat dijelaskan oleh guru dengan memperluas interrelasinya dengan pokok bahasan lainnya. Setidaknya guru dapat memberikan contoh-contoh adanya interrelasi antar faktor di permukaan bumi factor fisik-fisik, fisik-sosial, dan sosial-sosial, seperti adanya pengaruh pokok bahasan pola sebaran hutan dengan pokok bahasan iklim yang dipelajari. Guru perlu mendesain media, model dan strategi pembelajaran yang tepat untuk menguatkan adanya penerapan prinsip-prinsip geografi pada setiap pokok bahasan.

3. Pemberian contoh kejadian atau fenomena secara lokal, regional dan internasional.

Dalam konteks lokal seorang guru harus mampu memberi contoh dan ilustrasi kondisi dan masalah di lingkungan tempat tinggal peserta baik dalam bentuk narasi atau menunjukkan foto tentang situasi dan kondisi lingkungan, serta memberi tugas kepada peserta didik untuk mengobservasi lingkungan sekitar. Guru juga memberikan contoh bagaimana kondisi di lingkungan tempat tinggal memiliki persamaan di wilayah lain dalam skala regional ataupun internasional. Peserta didik akan menemukan jawaban dan solusi terhadap dari masalah di lingkungannya. 
4. Penggunaan media peta untuk menggambarkan potensi dan lingkungan wilayah tempat tinggal sekitar, maupun wilayah yang lebih luas yang menyebabkan peserta didik mengenali lokasi, keunikan dan pola sebarannya. Peta dapat dibuat oleh peserta didik, namun guru tidak hanya memintanya membuat peta tapi dapat menjelaskan makna dari penggunaan peta tersebut. Peta membantu peserta didik mendapatkan informasi sebanyak-banyaknya tentang pokok bahasan/topik kajian di permukaan bumi dalam sekala yang lebih luas ataupun semakin detil pada wilayah yang sempit.

5. Penyusunan bahan evaluasi yang mengukur dan menilai penerapan prinsip dan pendekatan geografi atau mental map itu sendiri. Soal-soal yang dibuat guru atau kisi-kisi portofolio untuk unjuk kerja peserta didik tidak hanya mengukur pengertian dari suatu pokok bahasan saja, melainkan pertanyaan-pertanyaan yang mengukur KD yang terintegrasi dengan prinsip dan pendekatan geografi. Pertanyaan yang mengandung analisis adanya interrelasi, pola, aksesibilitas, persebaran maupun interdependensi antar wilayah atau fenomena perlu diberikan kepada peserta didik untuk mengukur mental map peserta didik itu sendiri. Pertanyaan-pertanyaan yang bersifat mengukur ilmu bantu geografi sebaiknya dikurangi.

\section{Kesimpulan}

1. Mental map seseorang dapat dibangun dan dikembangkan secara bertahap dari pembelajaran geografi di sekolah.

2. Pembelajaran geografi merupakan pembelajaran yang mengembangkan mental map baik dalam perencanaan, pelaksanaan dan evaluasi.

3. Pengembangan mental map dalam pembelajaran geografi di kelas adalah suatu keniscayaan jika guru menerapkan prinsip-prinsip dan pendekatan geografi pada pembahasan setiap pokok bahasan. Pembelajaran geografi yang mengabaikan penerapan prinsip-prinsip dan pendekatan geografi akan mengurangi daya serap dan kapasitas mental map peserta didik.

4. Mental map peserta didik perlu dikembangkan untuk mencapai tujuan dari pembelajaran geografi yaitu menjadikan warga negara yang mengenali wilayahnya dalam sudut pandang lokal, nasional/regional dan internasional sehingga mampu berpikir kritis, menemukan jawaban dan memberikan solusi terhadap masalah di permukaan bumi.

\section{DAFTAR PUSTAKA}

Abdurachman, M.(1988) Geografi Perilaku: Suatu Pengantar Studi tentang Persepsi Lingkungan. Jakarta: Depdiknas.

Alfandi, W. (2001) Epistemologi Geografi. Yogyakarta: Gajah Mada University Press.

Anonim. (2006). The Important of Geography In The School Curriculum. Canadian Council For Geographic Education. Tersedia di www.cangeoeducation.ca/programs/geoliteracy/docs/importance_in_curriculum.pdf

Anonim. Geography tersedia di http://334.edb.hkedcity.net/doc/eng/framework1/geog.pdf

Barkowsk, T. (2002) Mental Representation and Processing of Geographic Knowledge. Berlin Heidelberg New York: Springer.

Bednardz, S, W, dkk. (1994) Geography For Life: National Geography Standards 1994. Washington, DC: Department of Education; National Endowment for the Humanities (NFAH); National Geographic Society

Benson, J. S. (2002) An Exercise In Mental Mapping. The Journal of Geography 99.1 (Jan/Feb 2000): 32.

Bergman, E.F dan Renwick, W.H. (2003) Introduction to Geography: People, Places and Environment. New Jersey: Pearson Education, Inc.

Delaware Geography Standard For Teacher. Tersedia di http://www.doe.k12.de.us/cms/lib09/DE01922744/Centricity/domain/66/clarifications/Geography\%209-12.doc 
Delaware Department of Education. Social Studies Standards-Geography. Tersedia dihttp://www1.udel.edu/cds/dapa/08-09/GLE/SS\%209-12.pdf. (diakses 8 April 2015)

Delaware Department of Education. Delaware Recommended Curriculum. http://www.doe.k12.de.us/cms/lib09/DE01922744/Centricity/domain/66/grade\%204/Developing\%20Mental\%20 Maps.doc.

Down, R. M. dan Stea, D. (1973) Image and Environment, Cognitive Mapping and Spatial Behavior. Chicago : Aldine Publising Company.

Dublin. (1999) Geography: Social, Environmental and Scientific Education Curriculum. The Stationery Office. Government of Ireland

Gagne, R. M. dan Briggs, L. J. (1992) Principles of Instructional Design. New Yorrk: Holt Rinehart \& Winston.

Getis and Fellmann. (2006) Introduction to Geography. New York : McGraw Hill.

Gould, P. dan White, R. (1974) Mental Maps. New York: Penguin Books Inc.

Heatwole, C.A. (2007) Changes in Mental Maps. Journal of Geography, 92:2, 50-55. New York : Department of Geology and Geography.

Mutakin, A dan Eridiana, W. (2008) Geografi Perilaku : Keragaman Perilaku Lingkungan. Bandung: Jurusan Pendidikan Geografi-FPIPS UPI.

Nelson, E.S. (1996) A Cognitive Map Experiment: Mental Representations and the Encoding Process. Cartography and Geographic Information Systems, v. 23(4): 229-248.

Ningrum, E.dan Waluya, B. (2008) Pengembangan Strategi Pembelajaran Geografi Berorientasi Pemahaman Konsep Kebencanaan. Makalah PIT IGI di Padang 22-23 November 2008. Bandung : Pendidikan Geografi UPI.

Otten, G.V. (2015) Cultural Intelligence, Applied Geography, and Homeland Security: Richard Hartshorne and The Nature of Geography. The Pennsylvania State University. Tersedia di https://www.eeducation.psu.edu/geog571/node/378 (diakses 9 September 2016)

Pennsylvania Department of Education. (2002) Academic Standards For Geography. Tersedia di http://www.stateboard.education.pa.gov/Documents/Regulations\%20and\%20Statements/State\%20Academic\% 20Standards/pdfgeography.pdf. (diakses 17 April 2015)

Purwanto, E. (2001) Pendekatan Pemahaman Citra Lingkungan Perkotaan (Melalui Kemampuan Peta Mental Pengamat). Dimensi Teknik Arsitektur Vol. 29, No. 1, Juli 2001: 85 - 92. Jurusan Teknik Arsitektur, Fakultas Teknik Sipil dan Perencanaan - Universitas Kristen Petra

(2010) Problematika Pembelajaran Geografi. Pidato Pengukuhan Guru Besar Dalam Bidang Pembelajaran Geografi 6 Mei 2010. Malang: Universitas Negeri Malang

Schenk, F.B. (2013) Mental Maps: The Cognitive Mapping of the Continent as an Object of Research of European History. Berlin: European History Online

Setiawan, I. (2006) Peningkata Kualitas Pembelajaran Geografi melalui Pengembangan Media Pendidikan. Jurnal. Gea Jurnal Pendidikan Geografi Vol 6 No. 2. Bandung: Universitas Pendidikan Indonesia

Sudas, I dan Gokten, C. (2012) Cognitive Maps Of Europe: Geographical Knowledge Of Turkish Geography Students Authors. European Journal of Geography. Vol 3 No.1 hlm. 41-56

Sukmadinata, N. (2004) Landasan Psikologi Proses Pendidikan. Bandung: Rosda.

Sumaatmadja, N. (1997) Metodologi Pembelajaran Geografi. Jakarta: Bumi Aksara.

(1996) Studi Geografi Suatu Pendekatan dan Analisa Keruangan. Bandung: Alumni

The Royal Canadian Geographical Society. (2001) Canadian National Standards for Geography: A Standards-Based Guide to $\quad K-12$ Geography. Tersedia di http://www.cangeoeducation.ca/resources/learning_centre/docs/canadian_geography_standards.pdf. (diakses 8 April 2015)

http://nationalgeographic.org/standards/national-geography-standards/2/ (diakses 14 Maret 2015, 19:36:10) 